\title{
Article \\ Chemical Properties of Heavy Metal-Contaminated Soils from a Korean Military Shooting Range: Evaluation of Pb Sources Using Pb Isotope Ratios
}

\author{
Inkyeong Moon ${ }^{1}$, Honghyun Kim ${ }^{2, *}$, Sangjo Jeong ${ }^{2}$, Hyungjin Choi ${ }^{2}$, Jungtae Park ${ }^{2}$ and Insung Lee ${ }^{3}$ \\ 1 Deep-Sea Mineral Resources Research Center, Korea Institute of Ocean Science and Technology, \\ Busan 49111, Korea; moonik@kiost.ac.kr \\ 2 Department of Civil Engineering and Environmental Sciences, Korea Military Academy, Seoul 01805, Korea; \\ sangjo.jeong@mnd.go.kr (S.J.); hjchoi@mnd.go.kr (H.C.); highparks@mnd.go.kr (J.P.) \\ 3 School of Earth and Environmental Sciences, Seoul National University, Seoul 08826, Korea; insung@snu.ac.kr \\ * Correspondence: khh90@mnd.go.kr
}

Citation: Moon, I.; Kim, H.; Jeong, S.; Choi, H.; Park, J.; Lee, I. Chemical Properties of Heavy Metal-

Contaminated Soils from a Korean Military Shooting Range: Evaluation of $\mathrm{Pb}$ Sources Using $\mathrm{Pb}$ Isotope Ratios. Appl. Sci. 2021, 11, 7099. https:// doi.org/10.3390/app11157099

Academic Editor: Elza Bontempi

Received: 11 June 2021

Accepted: 28 July 2021

Published: 31 July 2021

Publisher's Note: MDPI stays neutral with regard to jurisdictional claims in published maps and institutional affiliations.

Copyright: (c) 2021 by the authors. Licensee MDPI, Basel, Switzerland. This article is an open access article distributed under the terms and conditions of the Creative Commons Attribution (CC BY) license (https:// creativecommons.org/licenses/by/ $4.0 /)$.

\begin{abstract}
In this study, the geochemical properties of heavy metal-contaminated soils from a Korean military shooting range were analyzed. The chemical behavior of heavy metals was determined by analyzing the soil $\mathrm{pH}$, heavy metal concentration, mineral composition, and $\mathrm{Pb}$ isotopes. In total, 24 soil samples were collected from a Korean military shooting range. The soil samples consist of quartz, albite, microcline, muscovite/illite, kaolinite, chlorite, and calcite. Lead minerals, such as hydrocerussite and anglesite, which are indicative of a transformation into secondary mineral phases, were not observed. All soils were strongly contaminated with $\mathrm{Pb}$ with minor concentrations of $\mathrm{Cu}$, $\mathrm{Ni}, \mathrm{Cd}$, and $\mathrm{Zn}$. Arsenic was rarely detected. The obtained results are indicated that the soils from the shooting range are contaminated with heavy metals and have evidences of different degree of anthropogenic $\mathrm{Pb}$ sources. This study is crucial for the evaluation of heavy metal-contaminated soils in shooting ranges and their environmental effect as well as for the establishment of management strategies for the mitigation of environmental risks.
\end{abstract}

Keywords: heavy metal; shooting range; contaminated soil; lead concentration; lead isotope; Korean military shooting range

\section{Introduction}

Heavy metals (e.g., $\mathrm{Pb}, \mathrm{Cd}, \mathrm{Cu}, \mathrm{As}, \mathrm{Sn}$, and $\mathrm{Sb}$ ) are indicative of soil toxicity. They are potential sources of soil contamination and their mobility and availability affect the environment. In the previous studies, the effects of heavy metals on the environment, terrestrial biota, and human health were studied [1,2]. Heavy metals are transported via surface water and groundwater $[3,4]$ and affect the surrounding area. Soils from military shooting ranges have attracted attention because they are contaminated with high concentrations of heavy metals [1,3], which do not decompose but remain in the environment [4]. Soil contamination in military shooting ranges has been investigated in numerous previous studies [1,3,5-11].

Ammunition, such as lead shots or lead bullets, is a source of the $\mathrm{Pb}$ pollution and soil toxicity in military shooting areas [5]. Bullets mainly consist of metallic lead (90\%) and minor amounts of other heavy metals $[6,12]$. Lead is accumulated in the soil via the abrasion and weathering of the bullets [7]. After Pb bullets are fired, they come in contact with the soil and eventually are weathered. Fragmented and pulverized bullets lead to the $\mathrm{Pb}$ contamination of the soil [13]. Metallic $\mathrm{Pb}$ is converted into dissolved (soluble particle) and particulate $\mathrm{Pb}$ by oxidation, carbonation, and hydration reactions [6] and transported to the soil [14]. Dissolved and particulate $\mathrm{Pb}$ species are primarily incorporated into mineral phases such as cerussite $\left(\mathrm{PbCO}_{3}\right)$, hydrocerussite $\left[\mathrm{Pb}\left(\mathrm{CO}_{3}\right)_{2}(\mathrm{OH})_{2}\right]$, anglesite $\left(\mathrm{PbSO}_{4}\right)$, and 
massicot/plattnerite $(\mathrm{PbO})$ [15]. The physicochemical conditions of the soil control the weathering and mobility of the contaminants [2]. Therefore, the physicochemical properties of heavy metal-contaminated soil from shooting ranges and the heavy metal distribution must be determined to effectively manage and restore the soil [2].

Worldwide, thousands of shooting ranges are utilized for recreational activities and military training [2]. Soils from shooting ranges that have been operated for many years are generally heavily contaminated [5]. In the United States, more than 3 million $\mathrm{mg}$ of metallic $\mathrm{Pb}$ were associated with hunting and recreational shooting in the 20th century; the $\mathrm{Pb}$ concentration is continuously increasing at a rate of $\sim 60,000 \mathrm{mg}$ per year $[12,14-18]$. In soils in the Netherlands, Denmark, Canada, and England, 200 to $6000 \mathrm{mg}$ of metallic $\mathrm{Pb}$ has been detected [14]. In addition, it has been reported that metallic lead bullets in soils in Denmark can be preserved for 100-300 years [14]. In central Sweden, on average, $5 \%$ of metallic $\mathrm{Pb}$ in shooting range soil has been transformed into lead carbonate and lead sulfate over a period of 20 to 25 years [19]. In addition, 3400 to $5000 \mathrm{mg} / \mathrm{kg}$ of Pb has been reported in skeet shooting ranges in northern England and central Sweden [17,19]. However, heavy metal contaminated soils in shooting ranges have been rarely studied due to the limited accessibility [3]. In addition, the environmental effects of soil contamination are poorly understood and mitigation methods have yet to be established. In the Republic of Korea, 1400 active small arms firing ranges are in operation [20], but little information is available about the effects of heavy metals from $\mathrm{Pb}$ bullets on the soil in military shooting ranges [21].

To evaluate the $\mathrm{Pb}$ contamination of soil, the $\mathrm{Pb}$ distribution has been commonly analyzed in previous studies [3,19,22-24]. The $\mathrm{Pb}$ concentrations and $\mathrm{Pb}$ isotopic compositions of the bullets, pellets, and soils have rarely been considered $[6,10,11,25,26]$. Therefore, the aims of this study were to understand spatial distribution of $\mathrm{Pb}$ contamination and to quantify the $\mathrm{Pb}$ input in soils from Korean military shooting ranges using both $\mathrm{Pb}$ concentration and $\mathrm{Pb}$ isotopic data, which are considered to be powerful indicators of the soil contamination in shooting ranges as well as the $\mathrm{Pb}$ sources.

\section{Materials and Methods}

\subsection{Study Area and Sampling Site}

Soil samples from a shooting range in the Gyeonggi-do Province, South Korea, which has been operated by the Korean military for training for many years, were chosen for this study because of the considerable $\mathrm{Pb}$ bullet weathering and preservation. The shooting range consists of eight firing lanes. The sampling locations are shown in Figure 1. Soil was also collected from the drainage ditch in the vicinity of the first shooting lane because it may be a migration pathway for heavy metals. For comparison, soil samples were collected from an off-target shooting range site, which are referred to as background soils. Background soils are not affected by $\mathrm{Pb}$ contamination. In total, 24 soil samples were collected from the beaten zones of the third and sixth lanes, drainage ditch, and background including targets at the 100, 200, and $250 \mathrm{~m}$ transects. The distance between the third and sixth lanes was $24 \mathrm{~m}$, as indicated in Figure 1b. Samples were collected from surface $(0-10 \mathrm{~cm})$, subsurface $(10-30 \mathrm{~cm})$, and deeper $(30-50 \mathrm{~cm})$ soils (Figure 1). 


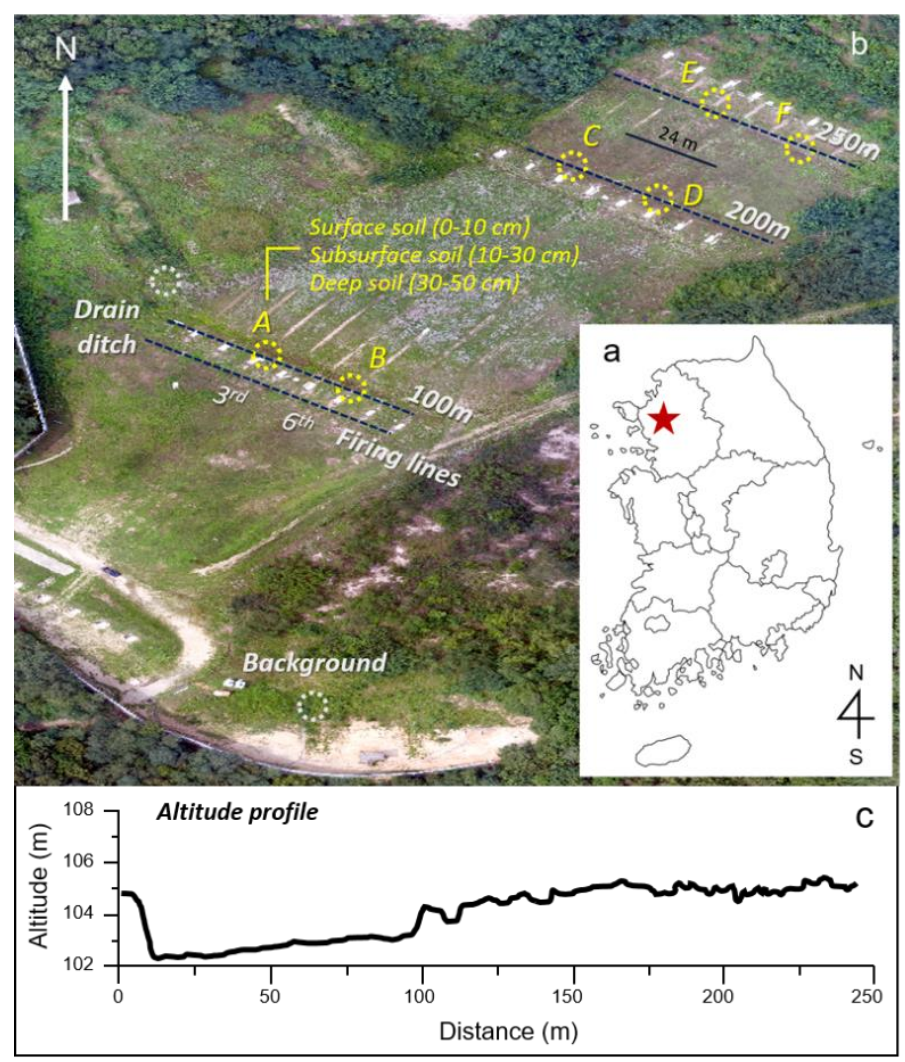

Figure 1. (a) Geological map of the Korean military shooting range in South Korea. (b) Specific soil sampling locations in the third (A, C, E) and sixth (B, D, F) shooting lanes. (c) Altitude profile of studied shooting range [22].

\subsection{Analytical Methods}

The elemental concentrations of $\mathrm{Cu}, \mathrm{Ni}, \mathrm{As}, \mathrm{Cd}, \mathrm{Pb}$, and $\mathrm{Zn}$ were determined at the Korea Military Academy using inductively coupled plasma-optical emission spectroscopy (ICP-OES, Perkin Elmer, Shelton, CT, USA). Powdered samples ( $3 \mathrm{~g}$ ) were dissolved in a 1:3 mixture of $\mathrm{HNO}_{3}$ to $\mathrm{HCl}$. A reflux condenser and absorption container were attached to the mixture container and $15 \mathrm{~mL}$ of $\mathrm{HNO}_{3}(0.5 \mathrm{M})$ was added to the absorption container over $16 \mathrm{~h}$. The extraction was carried out by slowly increasing the temperature to $120^{\circ} \mathrm{C}$ while circulating the coolant and heating it for $2 \mathrm{~h}$ at $120^{\circ} \mathrm{C}$. The temperature was then slowly lowered for $1 \mathrm{~h}$ to stop the coolant circulation. Subsequently, $10 \mathrm{~mL}$ of $0.5 / \mathrm{L} \mathrm{HNO}_{3}$ was poured into the absorption container and allowed to flow. Samples from the mixture container were filtered into a $100 \mathrm{~mL}$ volumetric flask using Whatman No. 40 filter paper. The flask was then filled to the marked line using $0.5 \mathrm{M} \mathrm{HNO}_{3}$. The samples were analyzed using ICP-OES. If the concentration exceeded the calibration range, the samples were diluted and reanalyzed to determine the exact concentration. The average values of three measurements were reported as results. The chemical properties of the soils are shown in Table 1.

The $\mathrm{Pb}$ isotope analyses were carried out on 15 samples at Activation Laboratories Ltd. (ActLabs, Ancaster, ON, Canada) using high resolution inductively coupled plasma mass spectrometry (HR-ICP-MS). The Pb isotope ratios were calibrated using the USGS SRM BCR-2. The ${ }^{208} \mathrm{~Pb} /{ }^{204} \mathrm{~Pb},{ }^{207} \mathrm{~Pb} /{ }^{204} \mathrm{~Pb}$, and ${ }^{206} \mathrm{~Pb} /{ }^{204} \mathrm{~Pb}$ ratios are presented in Table 2 . The $\mathrm{Pb}$ isotope values were calibrated using the common lead NIST standard 981. 
Table 1. The total $\mathrm{Cu}, \mathrm{Ni}, \mathrm{As}, \mathrm{Cd}, \mathrm{Pb}$, and $\mathrm{Zn}$ concentration (ppm) and $\mathrm{pH}$ in soils of shooting ranges.

\begin{tabular}{|c|c|c|c|c|c|c|c|c|c|}
\hline Soil & Distance from Firing Line (m) & Depth (cm) & $\mathrm{pH}$ & $\mathrm{Cu}$ & $\mathbf{N i}$ & As & Cd & $\mathrm{Pb}$ & $\mathrm{Zn}$ \\
\hline \multirow{9}{*}{ 6th shooting range } & \multirow{3}{*}{250} & 0 & 8.78 & 1,073 & 27 & 0 & 27 & 28,040 & 267 \\
\hline & & $5-15$ & 8.80 & 927 & 10 & 0 & 10 & 24,043 & 170 \\
\hline & & $15-30$ & 8.77 & 463 & 10 & 0 & 7 & 19,763 & 63 \\
\hline & \multirow{3}{*}{200} & 0 & 8.03 & 200 & 10 & 0 & 3 & 5127 & 0 \\
\hline & & $5-15$ & 8.30 & 183 & 13 & 0 & 3 & 4147 & 0 \\
\hline & & $15-30$ & 8.48 & 9 & 2 & 5 & 0 & 185 & 0 \\
\hline & \multirow{3}{*}{100} & 0 & 8.02 & 400 & 7 & 13 & 7 & 11,137 & 0 \\
\hline & & $5-15$ & 8.52 & 193 & 13 & 7 & 7 & 5297 & 0 \\
\hline & & $15-30$ & 8.64 & 217 & 13 & 3 & 3 & 4293 & 0 \\
\hline \multirow{9}{*}{ 3rd shooting range } & \multirow{3}{*}{250} & 0 & 8.94 & 643 & 10 & 0 & 3 & 20,030 & 90 \\
\hline & & $5-15$ & 8.80 & 580 & 10 & 0 & 3 & 13,987 & 137 \\
\hline & & $15-30$ & 8.76 & 623 & 10 & 0 & 3 & 17,303 & 60 \\
\hline & \multirow{3}{*}{200} & 0 & 7.50 & 273 & 13 & 13 & 13 & 6203 & 0 \\
\hline & & $5-15$ & 8.62 & 273 & 13 & 0 & 3 & 5313 & 0 \\
\hline & & $15-30$ & 8.67 & 210 & 13 & 0 & 3 & 7557 & 0 \\
\hline & \multirow{3}{*}{100} & 0 & 8.30 & 650 & 7 & 3 & 3 & 13,043 & 0 \\
\hline & & $5-15$ & 8.52 & 533 & 7 & 0 & 3 & 11,093 & 10 \\
\hline & & $15-30$ & 8.48 & 413 & 10 & 0 & 3 & 8140 & 3 \\
\hline \multirow{3}{*}{ Drain ditch } & \multirow{3}{*}{100} & 0 & 7.95 & 377 & 10 & 0 & 3 & 5417 & 3 \\
\hline & & $5-15$ & 8.28 & 493 & 10 & 0 & 3 & 6977 & 23 \\
\hline & & $15-30$ & 8.62 & 573 & 7 & 0 & 3 & 8740 & 63 \\
\hline \multirow{3}{*}{ Background } & \multirow{3}{*}{0} & 0 & 6.09 & 3 & 6 & 0 & 2 & 14 & 46 \\
\hline & & $5-15$ & 6.04 & 3 & 5 & 0 & 2 & 21 & 45 \\
\hline & & $15-30$ & 6.03 & 5 & 8 & 1 & 2 & 33 & 44 \\
\hline
\end{tabular}

Table 2. The $\mathrm{Pb}$ isotope ratio of soils of 6th shooting lane with drain ditch and background.

\begin{tabular}{|c|c|c|c|c|c|c|c|}
\hline Soil & $\begin{array}{c}\text { Distance from Firing } \\
\text { Line }(\mathrm{m})\end{array}$ & Depth $(\mathrm{cm})$ & ${ }^{208} \mathrm{~Pb} /{ }^{204} \mathrm{~Pb}$ & ${ }^{207} \mathrm{~Pb} /{ }^{204} \mathrm{~Pb}$ & ${ }^{206} \mathrm{~Pb} /{ }^{204} \mathrm{~Pb}$ & ${ }^{206} \mathrm{~Pb} /{ }^{207} \mathrm{~Pb}$ & ${ }^{208} \mathrm{~Pb} /{ }^{207} \mathrm{~Pb}$ \\
\hline \multirow{9}{*}{$\begin{array}{l}\text { 6th shooting } \\
\text { range }\end{array}$} & \multirow{3}{*}{250} & 0 & 38.77 & 15.69 & 18.53 & 1.18 & 2.47 \\
\hline & & $5-15$ & 38.21 & 15.45 & 18.26 & 1.18 & 2.47 \\
\hline & & $15-30$ & 38.96 & 15.65 & 18.50 & 1.18 & 2.49 \\
\hline & \multirow{3}{*}{200} & 0 & 38.09 & 15.53 & 18.46 & 1.19 & 2.45 \\
\hline & & 5-15 & 38.22 & 15.53 & 18.63 & 1.20 & 2.46 \\
\hline & & $15-30$ & 39.08 & 15.77 & 18.62 & 1.18 & 2.48 \\
\hline & \multirow{3}{*}{100} & 0 & 38.90 & 15.88 & 18.60 & 1.17 & 2.45 \\
\hline & & $5-15$ & 35.98 & 15.11 & 15.14 & 1.00 & 2.38 \\
\hline & & $15-30$ & 39.62 & 16.56 & 16.67 & 1.01 & 2.39 \\
\hline \multirow{3}{*}{ Drain ditch } & \multirow{3}{*}{100} & 0 & 37.97 & 15.53 & 15.77 & 1.02 & 2.44 \\
\hline & & $5-15$ & 38.98 & 16.12 & 16.41 & 1.02 & 2.42 \\
\hline & & $15-30$ & 38.79 & 16.03 & 16.26 & 1.01 & 2.42 \\
\hline \multirow{3}{*}{ Background } & \multirow{3}{*}{0} & 0 & 40.70 & 16.10 & 18.82 & 1.17 & 2.53 \\
\hline & & $5-15$ & 38.73 & 15.55 & 18.21 & 1.17 & 2.49 \\
\hline & & $15-30$ & 40.03 & 15.95 & 18.55 & 1.16 & 2.51 \\
\hline
\end{tabular}

The mineralogy of selected soil samples was analyzed with X-ray diffraction (XRD). The XRD analyses were conducted at the Korea Institute of Geoscience and Mineral Resources (KIGAM) using an X'Pert MPD diffractometer (Philips, Eindhoven, The Netherlands). The $X$-ray patterns were obtained from $3^{\circ}$ to $65^{\circ}$ ( $2 \theta$ range) at a scan rate of $2^{\circ}$ per minute.

The $\mathrm{pH}$ of the selected soils was determined following the standard method of APHA [27]. The soil samples were air-dried at room temperature, placed in a beaker 
to which distilled water was added, left for $1 \mathrm{~h}$ while stirring occasionally with a glass rod, and read within $60 \mathrm{~s}$ using a calibrated pH meter (XL-20, Thermo Fisher Scientific, Fair Lawn, NJ, USA). The soil $\mathrm{pH}$ was measured using a suspension of $25 \mathrm{~g}$ of soil in $25 \mathrm{~mL}$ of water, that is, a soil/water ratio of 1:1.

The elements $\mathrm{Cu}, \mathrm{Ni}, \mathrm{As}, \mathrm{Cd}, \mathrm{Pb}$, and $\mathrm{Zn}$ were mapped using an electron probe microanalyzer (EPMA, EPMA-1600, Shimadzu, Tokyo, Japan) at the Korea Basic Science Institute (KBSI), Jeonju Center, South Korea, and a wavelength-dispersive X-ray (WDS) system.

\section{Results and Discussion}

\subsection{Geochemical Properties of Soil}

The transport and distribution of heavy metals in soil in the shooting area results in serious heavy metal contamination [24]. As mentioned above, $\mathrm{Pb}$ is considered to be the primary contaminant, accounting for the largest proportion of heavy metal contamination [12,14-18]. Lead is insoluble [28] and insignificantly affected by secondary effects [29]. $\mathrm{The} \mathrm{Pb}$ mobility and solubility depend on the environmental conditions including the physicochemical properties of the soil, shooting range type, purpose of use, and vegetation (root exudates) $[2,5,30]$.

In general, a large proportion of $\mathrm{Pb}$ in the soil from shooting ranges and their vicinity is considered to originate from $\mathrm{Pb}$ shots [6]. The soil physicochemical properties and distribution of heavy metals in soils from Korea military shooting ranges have been analyzed in several previous studies. Lee and Park [31] evaluated the heavy metal contamination of soils in Maehyang-ri in the Gyeonggi-do shooting range. The shooting range was operated for 50 years until 2005. The Maehyang-ri area has been contaminated with heavy metals from explosives (trinitrotoluene, TNT; hexahydro-1,3,5-trinitro-1,3,5-triazine, RDX; and 1,3,5,7-tetranitro-1,3,5,7-tetrazocane, HDX) associated with bombs, practice bullets, ammunition, and unexploded ammunition [31]. Lee and Park [31] compared the heavy metal concentration in Maehyang-ri with that in other shooting ranges in South Korea and identified the major heavy metal contaminants in the Maehyang-ri shooting range. Based on their research, the $\mathrm{Cu}$ concentration in the study area is 23 times higher than that of soils in South Korea and the $\mathrm{Pb}$ concentration is 1.2 times higher than the soil pollution standard [31]. Kim and Jeong [22] investigated the heavy metal concentrations and distribution in soils, plants, and water samples in the same shooting area. They reported that the heavy metal concentration is the highest near the targets and that the proportion of $\mathrm{Pb}$ is higher than that of other heavy metals. Based on their results, both surface and deeper soils are enriched in heavy metals because of adsorption; however, they did not evaluate the heavy metal leaching from soil by surface water [22]. Several researchers have suggested that the $\mathrm{Pb}$ concentrations in the surface water and plants in the shooting range are significantly affected by the $\mathrm{Pb}$ concentration of the soil $[17,30,32]$.

The geochemical properties of the soils from the shooting range are presented in Table 1 . The $\mathrm{Pb}$ concentration in the vertical soil profiles of the shooting range is heterogeneous. Figure 2 shows that the $\mathrm{Pb}$ concentration is high regardless of the soil depth, which is due to the discharge of bullets at all depths and diffusion/transport of $\mathrm{Pb}$ [11]. In some firing ranges, arsenic (As) was not detected due to its low concentration. The $\mathrm{Pb}$ concentrations of the surface soils from the third and sixth shooting lanes were 100 to 1000 times higher than that of the background soil, respectively. Heavy metals are generally enriched in the surface soil compared with deeper soil, indicating the preferential contamination of the surface soil and mobilization through the soil profile (Figure 2) [24]. However, in the drain ditch, the heavy metal contents were highest in the deeper soil. It can be assumed that the leaching of heavy metals from the surface soil by water at the drain ditch had occurred [24]. It seems that the heavy metal accumulation processes due to several controlling factors had occurred during the 30-year operation period of the shooting range. The total $\mathrm{Pb}$ concentration of soils from the shooting range determined in this study is as high as values reported in previous studies and higher than the Korean pollution standard [3]. In Korea, the standard concentration in shooting ranges is $700 \mathrm{ppm}$ for $\mathrm{Pb}$; 
2000 ppm for $\mathrm{Cu}$; 2000 ppm for $\mathrm{Zn} ; 500$ ppm for Ni; 200 ppm for As; and 60 ppm for Cd [22]. $\mathrm{The} \mathrm{Pb}$ concentrations of soils in Cho-do and We-rye, Korea, exceeded 18,609 \pm 1202 and $3918 \pm 127$ ppm, respectively [3]. Similar results were obtained for an outdoor shooting range in Michigan, which was also contaminated with heavy metals [24]. Murray et al. [24] reported that the $\mathrm{Pb}, \mathrm{Cu}, \mathrm{Ni}, \mathrm{Cd}$, and $\mathrm{Zn}$ concentrations are 10 to 100 times higher than those of the background soil. The $\mathrm{Pb}$ concentration in soils from shooting ranges worldwide ranges from $\sim 10,000-70,000 \mathrm{mg} / \mathrm{kg}$ [2].
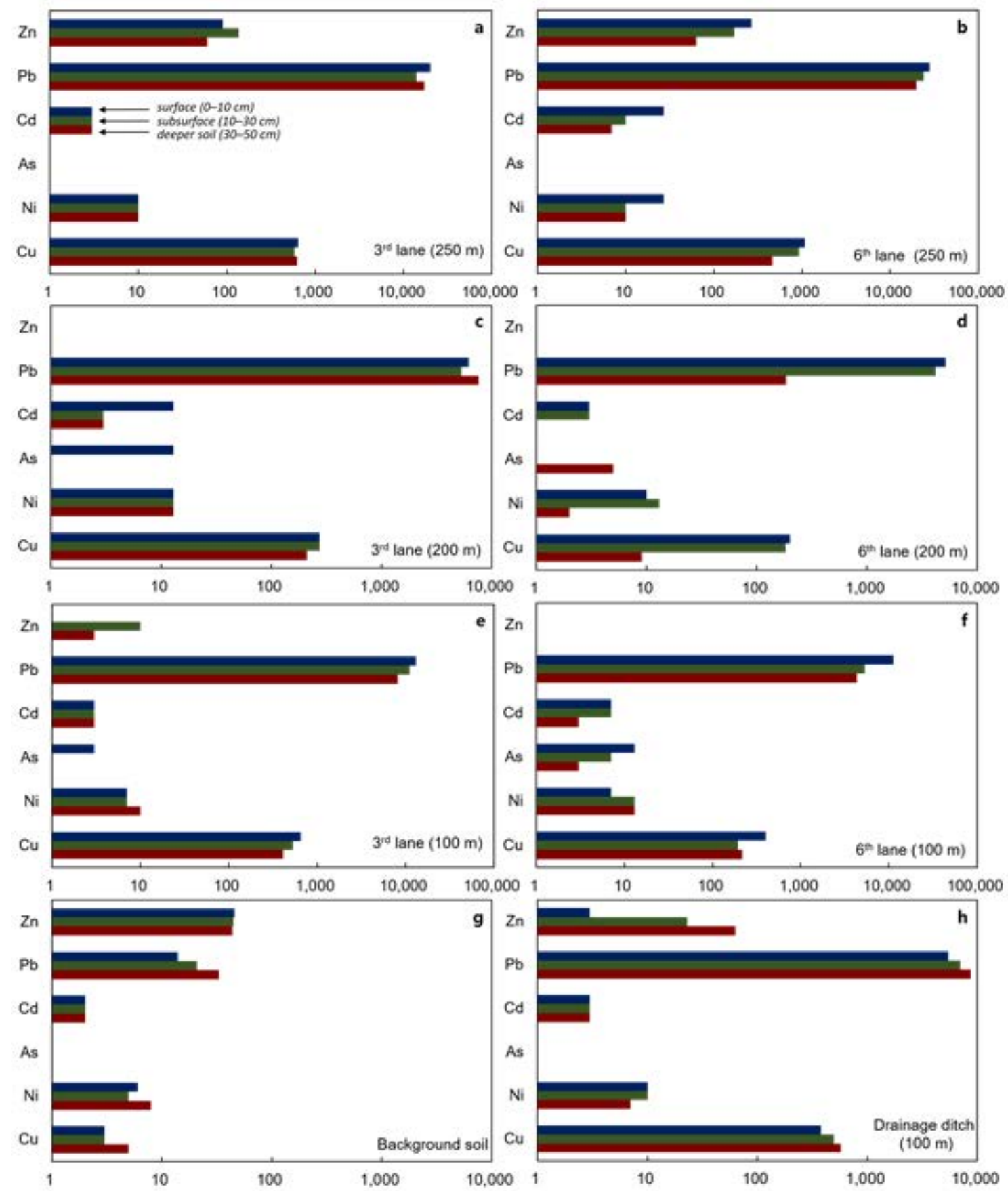

Figure 2. The $\mathrm{Zn}, \mathrm{Pb}, \mathrm{Cd}, \mathrm{As}, \mathrm{Ni}$, and Cu concentration (ppm) of soils from (a,c,e) 3rd and (b,d,f) 6th shooting lane with (g) background and (h) drain ditch for each transect. The blue, green, red bars are indicative of vertical soil profiles of surface $(0-10 \mathrm{~cm})$, subsurface $(10-30 \mathrm{~cm})$, and the deeper soil $(30-50 \mathrm{~cm})$.

This heavy metal enrichment can also be observed in the element maps obtained by EPMA analysis. Heavy metals, such as $\mathrm{Pb}, \mathrm{As}, \mathrm{Cd}, \mathrm{Ni}$, and $\mathrm{Zn}$, are distributed in certain 
minerals (Figure 3). Based on the XRD analysis, the predominant minerals are quartz, albite, microcline, muscovite/illite, kaolinite, chlorite, and calcite (Figure 4). Note that $\mathrm{Pb}$ minerals were not detected in this study. It can be assumed that the heavy metals from bullets are adsorbed at the mineral surfaces.

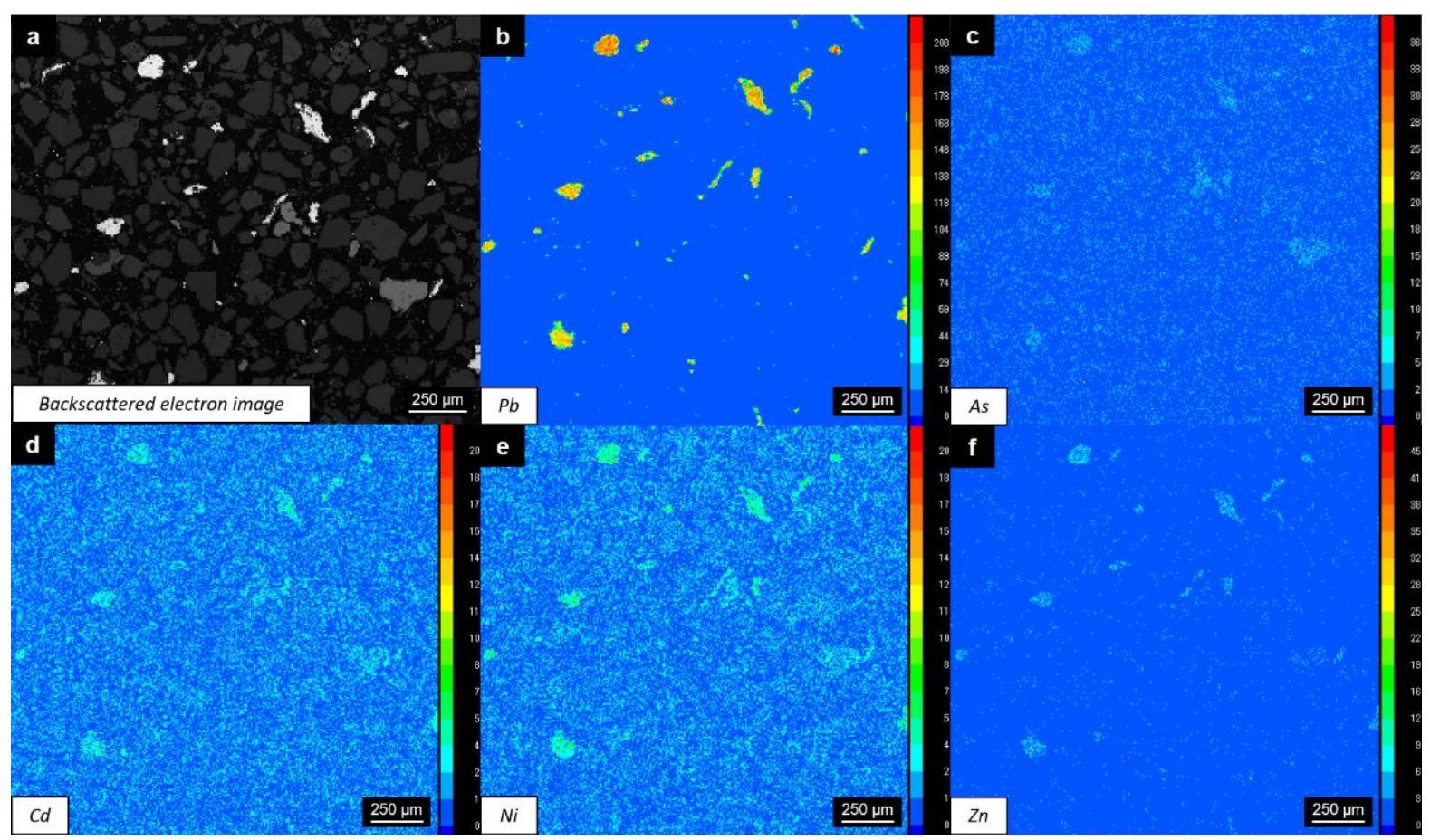

Figure 3. Element maps for (a) BSE image, (b) $\mathrm{Pb},(\mathbf{c}) \mathrm{As},(\mathbf{d}) \mathrm{Cd},(\mathbf{e}) \mathrm{Ni}$, and (f) $\mathrm{Zn}$ in soils from the shooting range obtained from EPMA analysis.

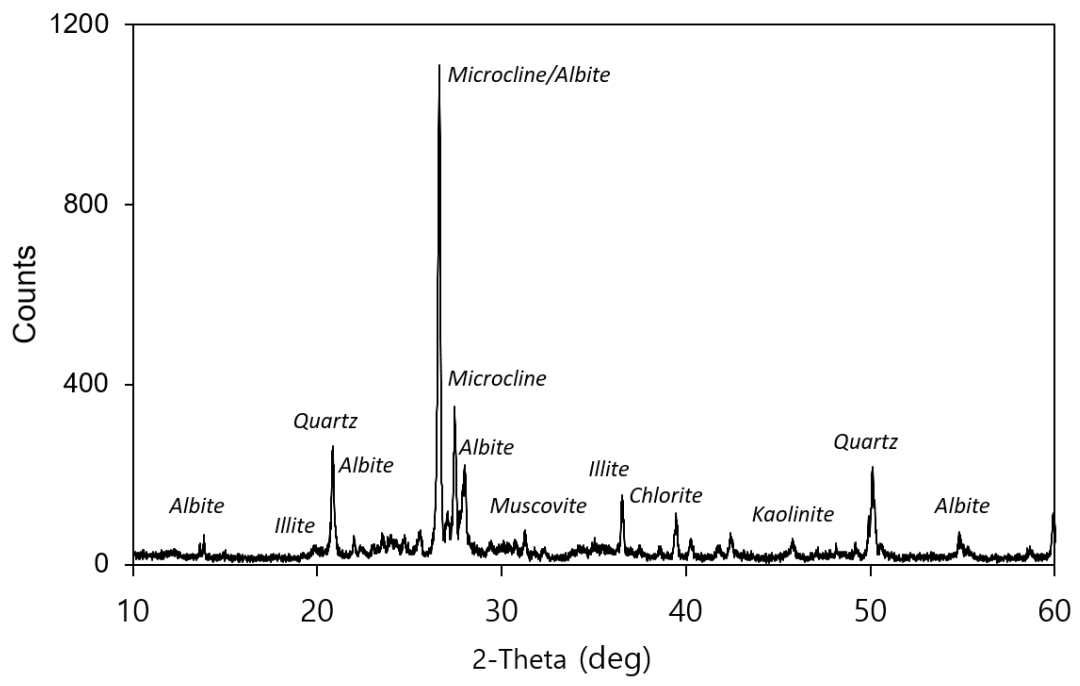

Figure 4. Representative mineralogical composition of soils from the shooting range determined using X-ray diffraction (XRD).

The $\mathrm{pH}$ values of the soils from the third and sixth shooting lanes and drainage ditch ( $\mathrm{pH}=7.50-8.94)$ are higher than that of the background soil $(\mathrm{pH}=\sim 6.00)$ at most targets in all transects, except for the $250 \mathrm{~m}$ transect in the third shooting lane (Figure 5, Table 1). This agrees with the results of a previous study [6] based on which the $\mathrm{pH}$ values of contaminated soils in shooting ranges in the Czech Republic (average $\mathrm{pH}=5.9$ ) are higher than those of the control sample (average $\mathrm{pH}=4.6$ ). The higher $\mathrm{pH}$ of the contaminated 
soil leads to the weathering of $\mathrm{Pb}$ bullets and transformation of metallic $\mathrm{Pb}$ into oxidized species [5]. During these processes, the consumption of $\mathrm{H}^{+}$ions within soil leads to an increase in the soil $\mathrm{pH}$ [6]. These $\mathrm{pH}$-dependent processes control the dissolution of $\mathrm{Pb}$ from bullets [6].

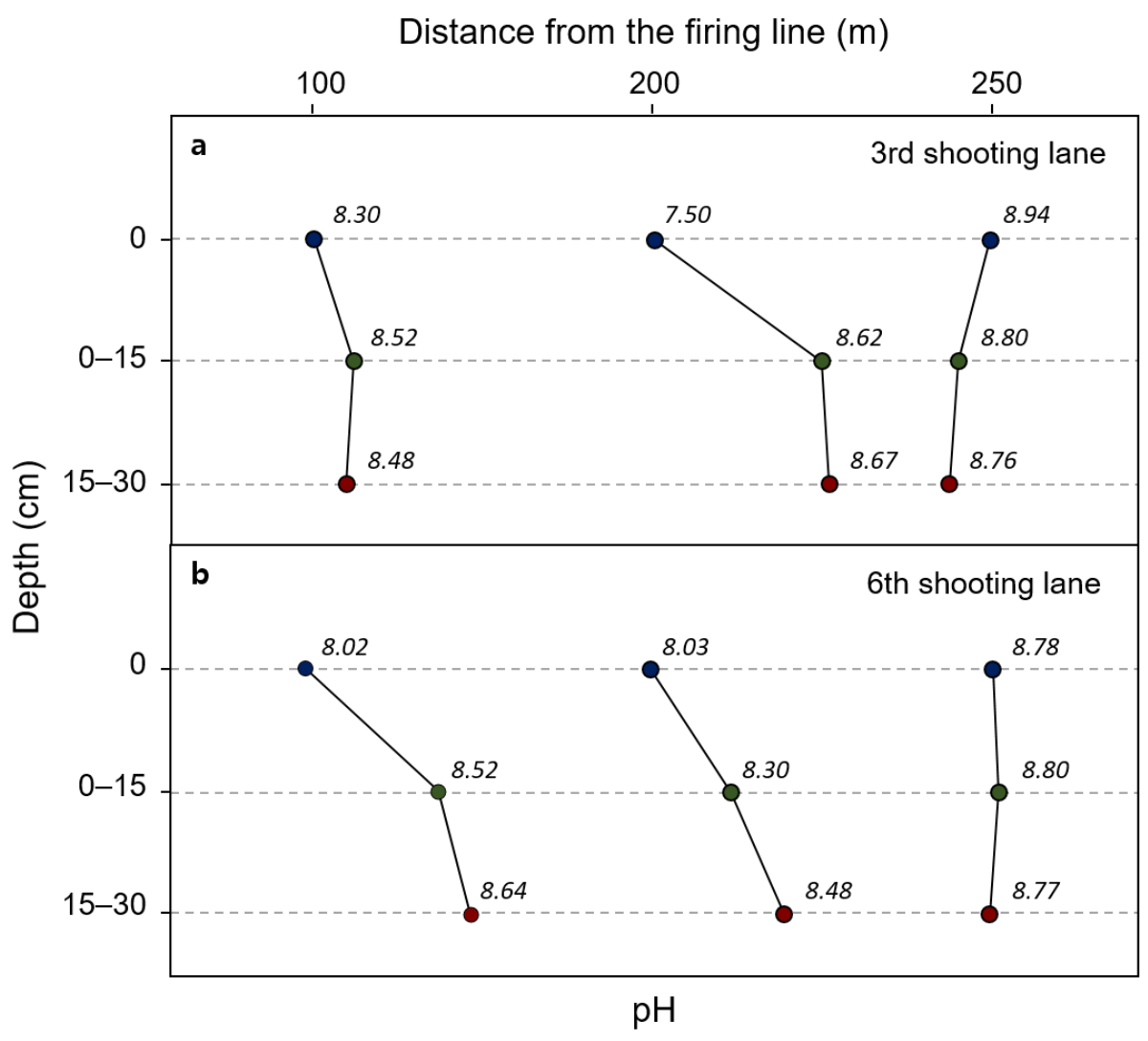

Figure 5. Depth profile of the $\mathrm{pH}$ of soils from the (a) third and (b) sixth shooting lanes of the shooting range.

Lead has four isotopes $\left({ }^{204} \mathrm{~Pb},{ }^{206} \mathrm{~Pb},{ }^{207} \mathrm{~Pb}\right.$, and $\left.{ }^{208} \mathrm{~Pb}\right)$ and the ${ }^{206} \mathrm{~Pb} /{ }^{207} \mathrm{~Pb}$ and ${ }^{208} \mathrm{~Pb} /{ }^{207} \mathrm{~Pb}$ ratios can be used as indicators of different sources [33]. The ${ }^{206} \mathrm{~Pb} /{ }^{207} \mathrm{~Pb}$ ratio is used as an indicator of anthropogenic $\mathrm{Pb}$ sources [6]. The $\mathrm{Pb}$ isotopic signatures are commonly used in environmental studies [10,11,34-38]. However, they have been rarely applied for the analysis of heavy metal contamination in soils from shooting ranges [6]. The $\mathrm{Pb}$ isotopes of soils from the sixth shooting lane (B, D, and F in Figure 1) were analyzed and compared with those of drainage ditch and background samples. The ${ }^{206} \mathrm{~Pb} /{ }^{207} \mathrm{~Pb}$ and ${ }^{208} \mathrm{~Pb} /{ }^{207} \mathrm{~Pb}$ ratios of the soils from the sixth shooting lane range from 1.171 to 1.199 and from 2.381 to 2.490 , respectively. The ${ }^{206} \mathrm{~Pb} /{ }^{207} \mathrm{~Pb}$ ratios of the drainage ditch and background sample are 1.014-1.018 and 1.163-1.171, respectively (Table 2). Kelepertzis et al. [35] investigated the $\mathrm{Pb}$ isotopes of urban soils in Athens. The ${ }^{208} \mathrm{~Pb} /{ }^{206} \mathrm{~Pb}$ and ${ }^{206} \mathrm{~Pb} /{ }^{207} \mathrm{~Pb}$ ratios displayed linear trends and plotted between the two endmembers of natural (high ${ }^{206} \mathrm{~Pb} /{ }^{207} \mathrm{~Pb}$ ) and anthropogenic (low ${ }^{206} \mathrm{~Pb} /{ }^{207} \mathrm{~Pb}$ ) sources [35]. This is consistent with our results. The ${ }^{208} \mathrm{~Pb} /{ }^{206} \mathrm{~Pb}$ and ${ }^{206} \mathrm{~Pb} /{ }^{207} \mathrm{~Pb}$ ratios of the soils analyzed in this study exhibit a negative correlation and plot between the two endmembers (Figure 6a). Their linear trend might be explained by the mixing of two different sources, which might be geological and anthropogenic materials [36,39]. The ${ }^{206} \mathrm{~Pb} /{ }^{207} \mathrm{~Pb}$ ratios of soils from the 200 and $250 \mathrm{~m}$ target lines of the sixth shooting lane were almost the same, indicating a similar $\mathrm{Pb}$ source [11]. Those soils were strongly contaminated with $\mathrm{Pb}$, and their $\mathrm{Pb}$ isotopic ratios are indicative of anthropogenic sources. The background soils displayed similar ${ }^{206} \mathrm{~Pb} /{ }^{207} \mathrm{~Pb}$ ratios, although their $\mathrm{Pb}$ concentrations were significantly lower (22 ppm on average). However, the subsurface soils, the deeper soils from the $100 \mathrm{~m}$ transect of the 
sixth shooting lane, and all soils from the drainage ditch had different ${ }^{206} \mathrm{~Pb} /{ }^{207} \mathrm{~Pb}$ ratios. This is related to the different sources of $\mathrm{Pb}$ contamination [40]. The lower $\mathrm{Pb}$ isotope values might be influenced by the background and geological factors [40]. As explained above, the heavy metal concentration in the drain ditch provides evidence of the influence of water on heavy metal diffusion and transport. Therefore, it can be assumed that the relatively lower $\mathrm{Pb}$ isotope values are indicative of a smaller contribution from anthropogenic sources. In other words, the values might represent a mixture of anthropogenic and geological $\mathrm{Pb}$ sources. Because no systematic trend between the $\mathrm{Pb}$ concentration or $\mathrm{pH}$ and $\mathrm{Pb}$ isotope ratios was observed in this study (Figure 6b), the correlations among $\mathrm{pH}, \mathrm{Pb}$ concentration, and $\mathrm{Pb}$ isotopes require further study. In summary, the heavy metal concentrations and $\mathrm{Pb}$ isotopic data demonstrate that the soils in Korean military shooting ranges are strongly contaminated with heavy metals and originate from different degree of anthropogenic sources.
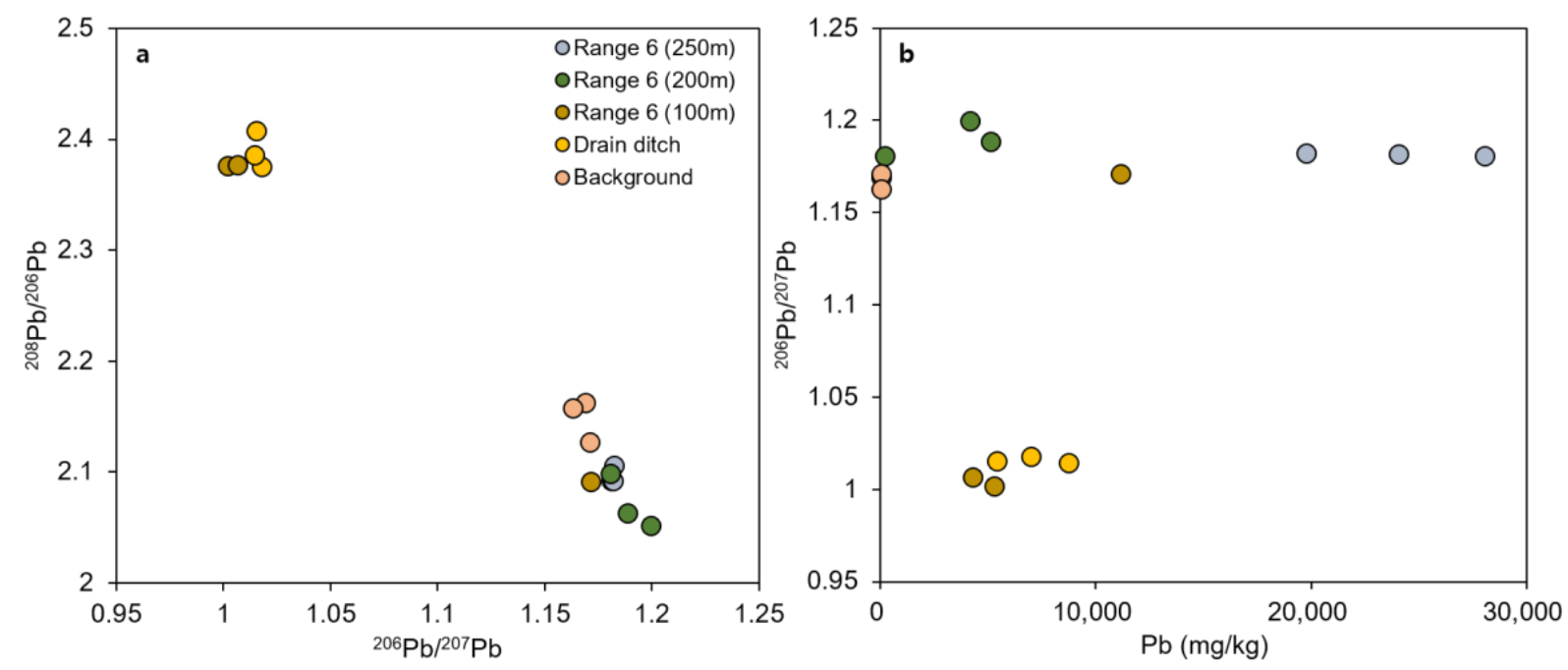

Figure 6. Plots of (a) ${ }^{208} \mathrm{~Pb} /{ }^{206} \mathrm{~Pb}$ vs. ${ }^{206} \mathrm{~Pb} /{ }^{207} \mathrm{~Pb}$ and $(\mathbf{b}){ }^{206} \mathrm{~Pb} /{ }^{207} \mathrm{~Pb}$ vs. $\mathrm{Pb}(\mathrm{mg} / \mathrm{kg}$ ) for soils from 6th lane of shooting range with drain ditch and background.

\subsection{Mineralogical Properties of Soil}

The collected soils were examined using XRD (Figure 4, Table 3) to determine the major crystalline phases or $\mathrm{Pb}$ minerals in the soils and to identify the transformation of $\mathrm{Pb}$ minerals. The predominant mineral components are quartz, albite, microcline, muscovite/illite, kaolinite, chlorite, and calcite. Carbonate is known to be one of the crucial sources for anthropogenic $\mathrm{Pb}$ [35]. The soils in this study generally contain calcite, representing direct evidence of anthropogenic $\mathrm{Pb}$ contribution. Hematite only occurs in the surface soil of the $200 \mathrm{~m}$ transect of the sixth shooting lane. Minerals carry toxic elements. As shown in the element maps, the minerals in the soil are enriched in $\mathrm{Pb}, \mathrm{Cd}, \mathrm{Ni}$, and $\mathrm{Zn}$. However, although the soils have high $\mathrm{Pb}$ concentrations, $\mathrm{Pb}$ minerals, such as hydrocerussite $\left(\mathrm{Pb}_{3}\left(\mathrm{CO}_{3}\right)_{2}(\mathrm{OH})_{2}\right)$, massicot $(\mathrm{PbO})$, hydroxypyromorphite $\left(\mathrm{Pb}_{10}\left(\mathrm{PO}_{4}\right)_{6}(\mathrm{OH})_{2}\right)$, cerussite $\left(\mathrm{PbCO}_{3}\right)$, and anglesite $\left(\mathrm{PbSO}_{4}\right)$, were not detected by XRD analysis in this study. This can be explained by the gradual transformation of $\mathrm{Pb}$ into secondary mineral phases in soils in shooting ranges [3]. The transformation processes are $\mathrm{pH}$-dependent; $\mathrm{Pb}$ is soluble under acidic conditions and poorly soluble under neutral and alkaline conditions. In summary, transformation products of acidic soils have a high solubility and high mobility, whereas transformation products of basic soils have a low solubility and attach to the bullet surface or remain in the surface soil [14]. For example, cerussite dissolves at low $\mathrm{pH}$ [41] and cerussite and/or hydrocerussite in acidic soil $(\mathrm{pH}=4.5)$ easily dissolves and transforms into ionic $\mathrm{Pb}^{2+}$ [9]. The soils in the study area are basic; therefore, the gradual transformation into $\mathrm{Pb}$ secondary minerals did occur. 
Table 3. The representative mineral components in shooting ranges.

\begin{tabular}{|c|c|c|c|}
\hline Soil & Distance from Firing Line (m) & Depth (cm) & Mineral Component \\
\hline \multirow{9}{*}{ 6th shooting range } & \multirow{3}{*}{250} & 0 & $\begin{array}{l}\text { Quartz, Albite, Microcline, Muscovite/Illite, } \\
\text { Kaolinite, Chlorite, Calcite }\end{array}$ \\
\hline & & $5-15$ & $\begin{array}{l}\text { Quartz, Microcline, Albite, Muscovite/Illite, } \\
\text { Kaolinite, Chlorite, Calcite }\end{array}$ \\
\hline & & $15-30$ & $\begin{array}{l}\text { Quartz, Microcline, Albite, Kaolinite, } \\
\text { Muscovite/Illite, Chlorite, Calcite }\end{array}$ \\
\hline & \multirow{3}{*}{200} & 0 & $\begin{array}{l}\text { Quartz, Albite, Microcline, Muscovite/Illite, } \\
\text { Kaolinite, Chlorite, Hematite }\end{array}$ \\
\hline & & $5-15$ & $\begin{array}{l}\text { Quartz, Microcline, Albite, Kaolinite, } \\
\text { Muscovite/Illite, Chlorite, Calcite }\end{array}$ \\
\hline & & $15-30$ & $\begin{array}{l}\text { Quartz, Muscovite/Illite, Albite, Microcline, } \\
\text { Kaolinite, Chlorite, Calcite }\end{array}$ \\
\hline & \multirow{3}{*}{100} & 0 & $\begin{array}{c}\text { Quartz, Albite, Microcline, Muscovite/Illite, } \\
\text { Kaolinite, Chlorite }\end{array}$ \\
\hline & & $5-15$ & $\begin{array}{c}\text { Quartz, Albite, Microcline, Muscovite/Illite, } \\
\text { Kaolinite, Chlorite }\end{array}$ \\
\hline & & $15-30$ & $\begin{array}{l}\text { Quartz, Albite, Microcline, Muscovite/Illite, } \\
\text { Kaolinite, Chlorite, Calcite, Hematite }\end{array}$ \\
\hline \multirow{3}{*}{ Drain ditch } & \multirow{3}{*}{100} & 0 & $\begin{array}{l}\text { Quartz, Microcline, Albite, Muscovite/Illite, } \\
\text { Kaolinite, Chlorite, Calcite }\end{array}$ \\
\hline & & 5-15 & $\begin{array}{l}\text { Quartz, Muscovite/Illite, Albite Microcline, } \\
\text { Kaolinite, Chlorite, Calcite }\end{array}$ \\
\hline & & $15-30$ & $\begin{array}{c}\text { Quartz, Albite, Microcline, Muscovite/Illite, } \\
\text { Kaolinite, Chlorite }\end{array}$ \\
\hline \multirow{3}{*}{ Background } & \multirow{3}{*}{0} & 0 & $\begin{array}{l}\text { Quartz, Albite, Microcline, Muscovite/Illite, } \\
\text { Kaolinite, Chlorite }\end{array}$ \\
\hline & & $5-15$ & $\begin{array}{l}\text { Quartz, Microcline, Albite, Muscovite/Illite, } \\
\text { Kaolinite, Chlorite }\end{array}$ \\
\hline & & $15-30$ & $\begin{array}{l}\text { Quartz, Microcline, Albite, Muscovite/Illite, } \\
\text { Kaolinite, Chlorite }\end{array}$ \\
\hline
\end{tabular}

\subsection{Potential Pb Contamination}

Shooting ranges are considered to be crucial sources of soil contamination with $\mathrm{Pb}$ [6]. In shooting ranges, $\mathrm{Pb}$ from bullets is accumulated and can be transferred into the soil as a major pollutant $[12,14-18]$. Soil contamination in the target area and its vicinity can result in serious environmental risks to groundwater, surface water, and plants $[5,16]$. Three migration pathways of $\mathrm{Pb}$ ammunition into the environment have been identified: (1) ingestion of bullets by wildlife and subsequent poisoning; (2) contamination of groundwater and wells; and (3) contamination of nearby aquatic ecosystems [42]. The mobility of water-soluble and exchangeable metals affects ecosystems [3]. The contamination of soils in shooting ranges and their vicinity represent an environmental hazard. Hence, contaminated soil must be managed to protect the environment [6].

\section{Conclusions}

In this study, the heavy metal $(\mathrm{Cu}, \mathrm{Ni}, \mathrm{As}, \mathrm{Cd}, \mathrm{Pb}$, and $\mathrm{Zn})$ contamination of soils in a Korean military shooting range was investigated by analyzing the heavy metal concentrations, $\mathrm{pH}$, mineral composition, and $\mathrm{Pb}$ isotopes. The results demonstrate that $\mathrm{Pb}$ plays a critical role in the contamination of soils in the shooting range and its vicinity. The soils are characterized by high concentrations of $\mathrm{Pb}$, which are representative heavy metal contaminants. The results suggest that heavy metals adhere to mineral surfaces. The soils are basic and composed of quartz, albite, microcline, muscovite/illite, kaolinite, chlorite, and calcite. Lead minerals were not observed in the soils because $\mathrm{Pb}$ was not transformed into secondary mineral phases. In addition, the $\mathrm{Pb}$ isotopic data are indicative of different 
degree of anthropogenic $\mathrm{Pb}$ sources. Therefore, it is necessary to investigate soils from shooting ranges to evaluate their environmental effects and develop some management strategies for the mitigation of $\mathrm{Pb}$ contamination in shooting ranges.

Author Contributions: I.M. and H.K. designed the study and wrote the manuscript; H.K., H.C., and J.P. performed chemical analyses; S.J., and I.L. contributed manuscript review and editing. All authors have read and agreed to the published version of the manuscript.

Funding: This research was funded by the Korea Institute of Ocean Science \& Technology (KIOST) project "Characterization of deep seabed mine tailings and development of environmentally friendly reduction/processing technologies," grant number PE99923, and the Hwarangdae Research Institute, Korea Military Academy, as part of its 2020 military-academic research project.

Institutional Review Board Statement: Not applicable.

Informed Consent Statement: Not applicable.

Data Availability Statement: Not applicable.

Acknowledgments: We are grateful to Hyeon Ih Ryu of the Korea Basic Science Institute (KBSI) for the EPMA analysis. We also thank Yeon Hee Lee of the Korea Military Academy (KMA) for the ICP-MS analysis. We would like to thank Editage (www.editage.co.kr, (16 June 2021).) for English language editing. In addition, please note that the contents of the paper are not an official position of the Korea military.

Conflicts of Interest: The authors declare no conflict of interest.

\section{References}

1. Basunia, S.; Landsberger, $\mathrm{S}$. Contents and leachability of heavy metals ( $\mathrm{Pb}, \mathrm{Cu}, \mathrm{Sb}, \mathrm{Zn}, \mathrm{As})$ in soil at the Pantex firing range, Amarillo, Texas. J. Air Waste Manag. Assoc. 2001, 51, 1428-1435. [CrossRef]

2. Sanderson, P.; Bolan, N.; Bowman, M.; Naidu, R. Distribution and availability of metal contaminants in shooting range soils around Australia. In Proceedings of the 19th World Congress of Soil Science: Soil Solutions for a Changing World, Brisbane, Australia, 1-6 August 2010; pp. 65-67.

3. Islam, M.N.; Nguyen, X.P.; Jung, H.-Y.; Park, J.-H. Chemical speciation and quantitative evaluation of heavy metal pollution hazards in two army shooting range backstop soils. Bull. Environ. Contam. Toxicol. 2016, 96, 179-185. [CrossRef]

4. Lee, K.-L.; Hyun, J.-H. Modality of Heavy Metal Contamination of Soil in Military Rifle Shooting Range. J. Soil Groundw. 2016, 21, 58-63. [CrossRef]

5. Cao, X.; Ma, L.Q.; Chen, M.; Hardison, D.W., Jr.; Harris, W.G. Weathering of lead bullets and their environmental effects at outdoor shooting ranges. J. Environ. Qual. 2003, 32, 526-534. [CrossRef] [PubMed]

6. Chrastný, V.; Komárek, M.; Hájek, T. Lead contamination of an agricultural soil in the vicinity of a shooting range. Environ. Monit. Assess. 2010, 162, 37-46. [CrossRef] [PubMed]

7. Hardison, D.W., Jr.; Ma, L.Q.; Luongo, T.; Harris, W.G. Lead contamination in shooting range soils from abrasion of lead bullets and subsequent weathering. Sci. Total Environ. 2004, 328, 175-183. [CrossRef] [PubMed]

8. Laidlaw, M.A.; Filippelli, G.; Mielke, H.; Gulson, B.; Ball, A.S. Lead exposure at firing ranges-A review. Environ. Health 2017, 16, 34. [CrossRef]

9. Li, Y.; Zhu, Y.; Zhao, S.; Liu, X. The weathering and transformation process of lead in China's shooting ranges. Environ. Sci. Process. Impacts 2015, 17, 1620-1633. [CrossRef]

10. Walraven, N.; Bakker, M.; van Os, B.; Klaver, G.T.; Middelburg, J.J.; Davies, G.R. Factors controlling the oral bioaccessibility of anthropogenic $\mathrm{Pb}$ in polluted soils. Sci. Total Environ. 2015, 506, 149-163. [CrossRef]

11. Tyszka, R.; Pietranik, A.; Kierczak, J.; Ettler, V.; Mihaljevič, M.; Medyńska-Juraszek, A. Lead isotopes and heavy minerals analyzed as tools to understand the distribution of lead and other potentially toxic elements in soils contaminated by Cu smelting (Legnica, Poland). Environ. Sci. Pollut. Res. 2016, 23, 24350-24363. [CrossRef]

12. Scheuhammer, A.M.; Norris, S.L. A Review of the Environmental Impacts of Lead Shotshell Ammunition and Lead Fishing Weights in Canada; Occas. Pap. Can. Wildl. Serv.: Ottawa, Canada, 1995.

13. Fayiga, A.; Saha, U. Soil pollution at outdoor shooting ranges: Health effects, bioavailability and best management practices. Environ. Pollut. 2016, 216, 135-145. [CrossRef]

14. Jørgensen, S.S.; Willems, M. The fate of lead in soils: The transformation of lead pellets in shooting-range soils. Ambio 1987, 16, 11-15.

15. Lin, Z. Secondary mineral phases of metallic lead in soils of shooting ranges from Örebro County, Sweden. Environ. Geol. 1996, 27, 370-375. [CrossRef]

16. Craig, J.; Rimstidt, J.; Bonnaffon, C.; Collins, T.K.; Scanlon, P.F. Surface water transport of lead at a shooting range. Bull. Environ. Contam. Toxicol. 1999, 63, 312-319. [CrossRef] [PubMed] 
17. Mellor, A.; McCartney, C. The effects of lead shot deposition on soils and crops at a clay pigeon shooting site in northern England. Soil Use Manage. 1994, 10, 124-129. [CrossRef]

18. Van Bon, J.; Boersema, J. Sources, Effects and Management of Metallic Lead Pollution. The Contribution of Hunting, Shooting and Angling. In Contaminated Soil' 88 ; Springer: Dordrecht, The Netherlands, 1988; pp. 269-271.

19. Lin, Z.; Comet, B.; Qvarfort, U.; Herbert, R. The chemical and mineralogical behaviour of Pb in shooting range soils from central Sweden. Environ. Pollut. 1995, 89, 303-309. [CrossRef]

20. MOE. The Development of Hybrid Electrokinetic Remediation Technique Using Solar Energy on Shooting Range Soils Contaminated by Heavy Metals, Gwachun, Kyunggi Republic of Korea; MOE: Gwachun, Korea, 2005; pp. 40-63.

21. Moon, D.H.; Cheong, K.H.; Khim, J.; Wazne, M.; Hyun, S.; Park, J.-H.; Chang, Y.-Y.; Ok, Y.S. Stabilization of Pb ${ }^{2+}$ and Cu ${ }^{2+}$ contaminated firing range soil using calcined oyster shells and waste cow bones. Chemosphere 2013, 91, 1349-1354. [CrossRef]

22. Kim, H.-H.; Jeong, S. Heavy Metal Pollution and Management Direction of Small Arms Firing Ranges. J. KIMS Technol. 2019, 22, 724-734.

23. Ma, L.Q.; Hardison, D.W.; Harris, W.G.; Cao, X.; Zhou, Q. Effects of soil property and soil amendment on weathering of abraded metallic $\mathrm{Pb}$ in shooting ranges. Water Air Soil Pollut. 2007, 178, 297-307. [CrossRef]

24. Murray, K.; Bazzi, A.; Carter, C.; Ehlert, A.; Ham's, A.; Kopec, M.; Richardson, J.; Sokol, H. Distribution and mobility of lead in soils at an outdoor shooting range. Soil Sediment Contam. 1997, 6, 79-93. [CrossRef]

25. Sjåstad, K.-E.; Simonsen, S.L.; Andersen, T.H. Lead isotope ratios for bullets, a descriptive approach for investigative purposes and a new method for sampling of bullet lead. Forensic Sci. Int. 2014, 244, 7-15. [CrossRef] [PubMed]

26. Zeichner, A.; Ehrlich, S.; Shoshani, E.; Halicz, L. Application of lead isotope analysis in shooting incident investigations. Forensic Sci. Int. 2006, 158, 52-64. [CrossRef]

27. APHA. Standard Methods for the Examination of Water and Wastewater; American Public Health Association, American Water Works Association, and Water Environment Federation: Washington, DC, USA, 1998; pp. 3-37.

28. Mann, A.; Deutscher, R. Solution geochemistry of lead and zinc in water containing carbonate, sulphate and chloride ions. Chem. Geol. 1980, 29, 293-311. [CrossRef]

29. Bindler, R.; Renberg, I.; Klaminder, J.; Emteryd, O. Tree rings as Pb pollution archives? A comparison of ${ }^{206} \mathrm{~Pb} /{ }^{207} \mathrm{~Pb}$ isotope ratios in pine and other environmental media. Sci. Total Environ. 2004, 319, 173-183. [CrossRef]

30. Rooney, C.; McLaren, R.; Cresswell, R. Distribution and phytoavailability of lead in a soil contaminated with lead shot. Water Air Soil Pollut. 1999, 116, 535-548. [CrossRef]

31. Lee, J.-H.; Park, K.-S. Heavy metal distribution in soils from the Maehyang-ri inland shooting range area. J. Korean Soc. Water Environ. 2008, 24, 407-414.

32. Stansley, W.; Widjeskog, L.; Roscoe, D.E. Lead contamination and mobility in surface water at trap and skeet ranges. Bull. Environ. Contam. Toxicol. 1992, 49, 640-647. [CrossRef]

33. Komárek, M.; Chrastný, V.; Ettler, V.; Tlustoš, P. Evaluation of extraction/digestion techniques used to determine lead isotopic composition in forest soils. Anal. Bioanal. 2006, 385, 1109-1115. [CrossRef] [PubMed]

34. Dos Santos, N.; do Nascimento, C.; de Souza Júnior, V.; Southard, R.J.; de Olinda, R.A. Lead isotope distribution and enrichment factors in soil profiles around an abandoned Pb-smelter plant. Int. J. Environ. Sci. Technol. 2017, 14, 2331-2342. [CrossRef]

35. Kelepertzis, E.; Komárek, M.; Argyraki, A.; Šillerová, H. Metal (loid) distribution and Pb isotopic signatures in the urban environment of Athens, Greece. Environ. Pollut. 2016, 213, 420-431. [CrossRef] [PubMed]

36. Komárek, M.; Ettler, V.; Chrastný, V.; Mihaljevic, M. Lead isotopes in environmental sciences: A review. Environ. Int. 2008, 34, 562-577. [CrossRef]

37. Patel, M.M.; Adrianne, H.; Jones, R.; Jarrett, J.; Berner, J.; Rubin, C.S. Use of lead isotope ratios to identify sources of lead exposure in Alaska Natives. Int. J. Circumpolar Health 2008, 67, 261-268. [CrossRef]

38. Zhu, Y.; Kashiwagi, K.-i.; Sakaguchi, M.; Aoki, M.; Fujimori, E.; Haraguchi, H. Lead isotopic compositions of atmospheric suspended particulate matter in Nagoya City as measured by HR-ICP-MS. J. Nucl. Sci. Technol. 2006, 43, 474-478. [CrossRef]

39. Ettler, V.; Mihaljevič, M.; Šebek, O.; Molek, M.; Grygar, T.; Zeman, J. Geochemical and Pb isotopic evidence for sources and dispersal of metal contamination in stream sediments from the mining and smelting district of Přibram, Czech Republic. Environ. Pollut. 2006, 142, 409-417. [CrossRef] [PubMed]

40. Hopper, J.; Ross, H.; Sturges, W. Regional source discrimination of atmospheric aerosols in Europe using the isotopic composition of lead. Tellus B 1991, 43, 45-60. [CrossRef]

41. Zhang, P.; Ryan, J.A. Transformation of $\mathrm{Pb}$ (II) from cerrusite to chloropyromorphite in the presence of hydroxyapatite under varying conditions of pH. Environ. Sci. Technol. 1999, 33, 625-630. [CrossRef]

42. Violence Policy Center. The Health Risks of Shooting Ranges and Lead to Children, Families, and the Environment. In Poisonous Pastime; Environmental Working Group: Washington, DC, USA, 2001. 